\title{
A GEOMORPHIC MONITORING AND ADAPTIVE ASSESSMENT FRAMEWORK TO ASSESS THE EFFECT OF LOWLAND FLOODPLAIN RIVER RESTORATION ON CHANNEL-FLOODPLAIN SEDIMENT CONTINUITY
}

\author{
J. L. FLORSHEIM, ${ }^{\mathrm{a}} *$ J. F. MOUNT ${ }^{\mathrm{a}}$ and C. R. CONSTANTINE ${ }^{\mathrm{b}}$ \\ ${ }^{a}$ Geology Department and Center for Integrated Watershed Science and Management, University of California, One Shields Avenue, Davis, \\ CA 95616, USA \\ b Now at Department of Geological Sciences, University of California, Santa Barbara, CA 93106, USA
}

\begin{abstract}
The state of the science of lowland river floodplain restoration reflects the relatively new and experimental nature of large river floodplain rehabilitation efforts. Based on results of a case study of floodplain restoration at the lowland Cosumnes River, California, we present a geomorphic monitoring and adaptive assessment framework that addresses the need to inform and utilize scientific knowledge in lowland floodplain river restoration activities. Highlighting hydrogeomorphic processes that lead to habitat creation, we identify a discharge threshold for connectivity and sediment transfer from the channel to the floodplain and integrate discharge magnitude and duration to quantify a threshold to aid determination of when geomorphic monitoring is warranted. Using floodplain sand deposition volume in splay complexes as one indicator of dynamic floodplain habitat, we develop a model to aid prediction of the sand deposition volume as an assessment tool to use to analyze future monitoring data. Because geomorphic processes that form the physical structure of a habitat are dynamic, and because the most successful restoration projects accommodate this fundamental characteristic of ecosystems, monitoring designs must both identify trends and be adapted iteratively so that relevant features continue to be measured. Thus, in this paper, adaptive assessment is defined as the modification of monitoring and analysis methods as a dynamic system evolves following restoration activities. The adaptive monitoring and assessment methods proposed facilitate long-term measurements of channel-floodplain sediment transfer, and changes in sediment storage and morphology unique to lowland river-floodplain interactions and the habitat that these physical processes support. The adaptive assessment framework should be integrated with biological and chemical elements of an interdisciplinary ecosystem monitoring program to answer research hypotheses and to advance restoration science in lowland floodplain river systems. Copyright (C) 2005 John Wiley \& Sons, Ltd.
\end{abstract}

KEY WORDS: lowland river; floodplain; sediment continuity; restoration; geomorphic monitoring; adaptive assessment; adaptive management

\section{INTRODUCTION}

Monitoring dynamic geomorphic processes in lowland floodplain rivers is an essential element of integrated adaptive assessment and management of lowland river restoration efforts. Because of the significant global loss of floodplain wetland biodiversity, there is a critical need to restore physical processes that sustain function in floodplain rivers (Tockner and Stanford, 2002). This paper illustrates development of a long-term adaptive monitoring and assessment framework for lowland rivers, utilizing results of geomorphic monitoring of a restoration project at the Cosumnes River Preserve as a case study (Figure 1). This framework addresses restoration of channelfloodplain connectivity and the physical structure of evolving floodplain habitat following construction of intentional levee breaches for floodplain restoration. We present a conceptual sediment continuity model applicable to assessment of geomorphic interactions between the river channel and floodplain restoration area. Moreover, we identify a flow magnitude-duration threshold associated with sediment transfer from the channel to the floodplain

*Correspondence to: Joan L. Florsheim, Geology Department, University of California, Davis, CA 95616.

E-mail: florsheim@geology.ucdavis.edu

Received 28 April 2004

Revised 15 May 2005

Copyright (C) 2005 John Wiley \& Sons, Ltd.

Accepted 7 June 2005 


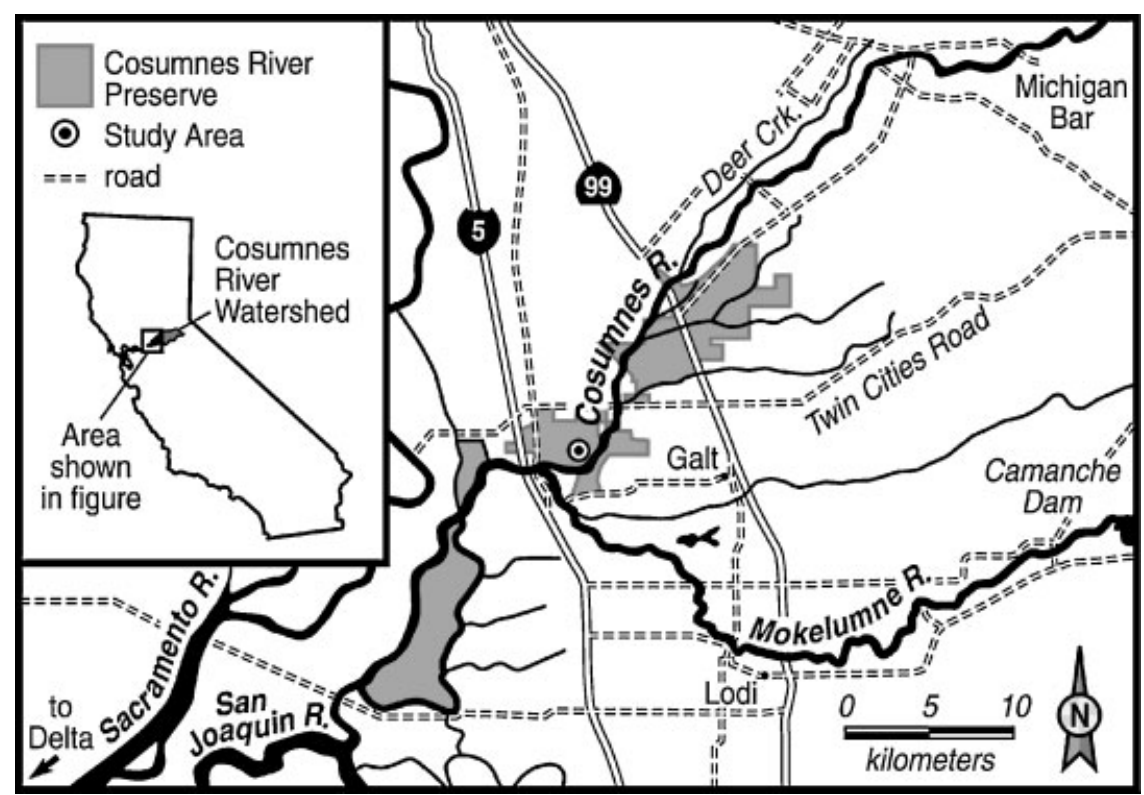

Figure 1. The lowland Cosumnes River in the Central Valley, CA, flows southwest from the Sierra Nevada to its confluence with the Mokelumne River upstream of the Sacramento-San Joaquin River Delta; note the location of the Cosumnes River Preserve floodplain restoration area

restoration area, which may be used as a trigger to determine when to initiate monitoring. These assessment tools and the overall geomorphic monitoring and adaptive assessment framework may be applied broadly to a range of adaptive monitoring, assessment, and management objectives in lowland river-floodplain systems in California's Central Valley or in lowland river systems globally.

\section{Adaptive assessment and management}

Adaptive management, first defined by Holling (1978), is an approach that includes continual and systematic acquisition of knowledge of a system in order to improve management over time. Adaptive management approaches acknowledge the uncertainty inherent in our understanding of natural systems, design management actions as experiments in order to reduce this uncertainty, and integrate information in an iterative process (Walters and Holling, 1990; Irwin and Wigley, 1993; Parma and NCEAS Working Group on Population Management, 1998; Wilhere, 2002). Adaptive management relies on a hypothesis-driven conceptual model of the dominant processes affecting how a system functions, and these hypotheses may be tested through long-term monitoring designed accordingly. Evaluation, interpretation and communication of monitoring data are essential in adaptive management, and mechanisms to facilitate these key components are (or should be) developed concurrently with management plans. Thus, adaptive management usually refers to the project-specific adjustments needed in order to learn from and improve upon project performance (CALFED, 1998) and to improve the likelihood that a restoration effort will be effective. Downs and Kondolf (2002) promote such detailed post-project data collection to evaluate project effectiveness and to improve future channel restoration designs. The terms 'adaptive management' and 'adaptive assessment' are often used interchangeably. However, in this paper, we reserve the term 'adaptive assessment' to refer to modifications in monitoring and analysis methods needed to document changes that occur as dynamic systems evolve following restoration efforts. As these changes become apparent through analysis and interpretation of data, they may then be used to inform and refine restoration science and management.

\section{Monitoring lowland river-floodplain interactions}

Effective monitoring and assessment of lowland river floodplains require a firm understanding of the geomorphic processes responsible for their formation and evolution. In lowland rivers, anabranching or anastomosing 
channel networks formed by episodic avulsion dominate floodplain geomorphology (Brown, 1996; Smith et al., 1989; Nanson and Croke, 1992; Richards et al., 1993; Slingerland and Smith, 2004). Sediment erosion and deposition processes that create and maintain the physical structure of lowland floodplain habitat differ significantly from processes in higher-energy fluvial systems (Nanson and Croke, 1992; Florsheim, 2004).

Lowland river floodplain-channel interactions influence vegetation recruitment and establishment. Subsequent sediment-vegetation feedback influences floodplain dynamics and topographic evolution (Marston et al., 1995; Gurnell, 1995; Hupp and Osterkamp, 1996; Mount et al., 2002; O’Connor et al., 2002, Richards et al., 2002; Steiger and Gurnell, 2003) and floodplain sediment storage. Floodplain biodiversity relies in part on the resulting geomorphic structure, or floodplain topography (Bravard et al., 1985; Amoros et al., 1987; Petts, 1990; Pinay et al., 1990; Sparks et al., 1990; Wissmar and Swanson, 1990; Bayley, 1991; Stanford et al., 1996; Junk et al., 1989; Ward et al., 1999; Ward and Tockner, 2001; Tockner and Stanford, 2002; Florsheim and Mount, 2002; Palmer et al., 2005; Schnitzler et al., 2005).

Sediment deposited on lowland river floodplains comprises one component of a river's multi-dimensional transfer and storage system. Longitudinal, lateral and vertical continuity and connectivity of the floodplain and channels during various flood magnitudes over time account for creation and maintenance of floodplain topography and biodiversity. Longitudinal continuity influences downstream sediment supply and floodplain processes (Ward and Stanford, 1995; Ward et al., 1999; Stanford and Ward, 2001). Lateral continuity, referred to as the 'flood pulse' (Junk et al., 1989), transfers water and sediment from channels onto floodplains. Thus, floodplain hydrology, including magnitude and duration of overbank flows, is a critical factor in river restoration, management (Galat et al., 1998; Poff et al., 1997; Richter et al., 1997) or mitigation efforts (Bedford, 1996).

Ecological methods for assessment and management recognize the critical importance of geomorphic processes and floods (Amoros et al., 1987; Petts et al., 1992; Sparks et al., 1998). Although numerous studies document the critical role of longitudinal and lateral connectivity in floodplain restoration, studies that develop specific monitoring protocols and measurements needed to address interactions between water and sediment in lowland rivers have received less attention. Moreover, few studies detail geomorphic monitoring protocols required as a scientific basis for adaptive assessment and management of lowland floodplain river restoration projects. Exceptions include the work of Rhoads and Miller (1990) that outlines a framework for long-term measurement of elements of a sediment budget in order to distinguish project-related impacts on the main channel from natural channel evolution of constructed wetlands on a floodplain in Illinois. Wheaton et al. (2004) propose development of a spawning habitat rehabilitation design through hypothesis construction and testing. Thorne (2002) outlines a framework to assess large alluvial rivers with meandering and braided patterns. These and other studies identify monitoring as a critical step in design and assessment of restoration projects (Brookes, 1996; Downs and Kondolf, 2002) or address monitoring methods in higher-energy river channels without floodplains (MacDonald et al., 1991). Montgomery and MacDonald (2002) utilize a hierarchical classification of channel morphology in mountain rivers (Montgomery and Buffington, 1997) as a framework for monitoring geomorphic processes. However, in lowland floodplain-river systems, processes operating on floodplains outside the main channel are critical to habitat function. In order to fill the gap in lowland river monitoring protocols, we specifically address the geomorphic monitoring design parameters, locations and methods intended to improve scientific knowledge of lowland channel-floodplain interactions resulting from restoration efforts using the Cosumnes River floodplain restoration project as a case study. The Cosumnes River is a major tributary within California's Sacramento and San Joaquin River watershed.

In the Sacramento and San Joaquin River systems, California's largest watershed, almost $4000 \mathrm{~km}^{2}$ of floodplain riparian habitat have been converted to agriculture and other land uses over the past two centuries (TBI, 1998). Changes in sediment supply and channel-floodplain connectivity resulting from basin-wide land use change contributed to a significant decline in complexity and to the listing of multiple threatened and endangered aquatic and terrestrial species. The loss of floodplain habitat in the Sacramento-San Joaquin River watershed in the Central Valley, CA (Figure 1) has led to considerable recent efforts to restore lowland river floodplain habitat (CALFED, 1998). Although a 30-year monitoring period is requisite in the $\$ 300$ million California Bay-Delta Authority (CBDA, formerly called CALFED) Ecosystem Restoration Program, to date, there has been no development of a long-term adaptive monitoring and assessment framework to advance the science needed to assess the effectiveness of these floodplain restoration efforts. The scope of this monitoring paper covers the geomorphic component of an applied interdisciplinary research program underway by the UC Davis Cosumnes Research 
Group (http://watershed.ucdavis.edu/crg/). Whereas specific elements of the geomorphic monitoring program defined in this paper may be applied locally as one component of an interdisciplinary research program underway for the lower Cosumnes River, the geomorphic monitoring and adaptive assessment framework defined in this paper may be applied to lowland rivers in other areas.

\section{LONG-TERM GEOMORPHIC MONITORING AND ADAPTIVE ASSESSMENT FRAMEWORK}

\section{A Lowland river monitoring and adaptive assessment framework}

We build on the knowledge gained from detailed field investigations and analyses of pre-disturbance conditions in the Cosumnes River and the levee breach floodplain restoration area (Constantine, 2001; Florsheim and Mount, 2002, 2003; Constantine et al., 2003) and recent observations to develop a three-phase monitoring and adaptive assessment framework within the context of the physical characteristics unique to the Cosumnes watershed, its legacy of land use disturbances and the goals of the levee-breach restoration project at the Cosumnes River Preserve (Figure 2). The framework is intended to guide data collection to answer specific research hypotheses and to facilitate data analysis, interpretation, communication and integration of the physical and biological aspects of ecosystem process and function. The framework suggests that development of the restoration project design should follow interpretation of pre-disturbance conditions and baseline studies. However, as in many other restoration

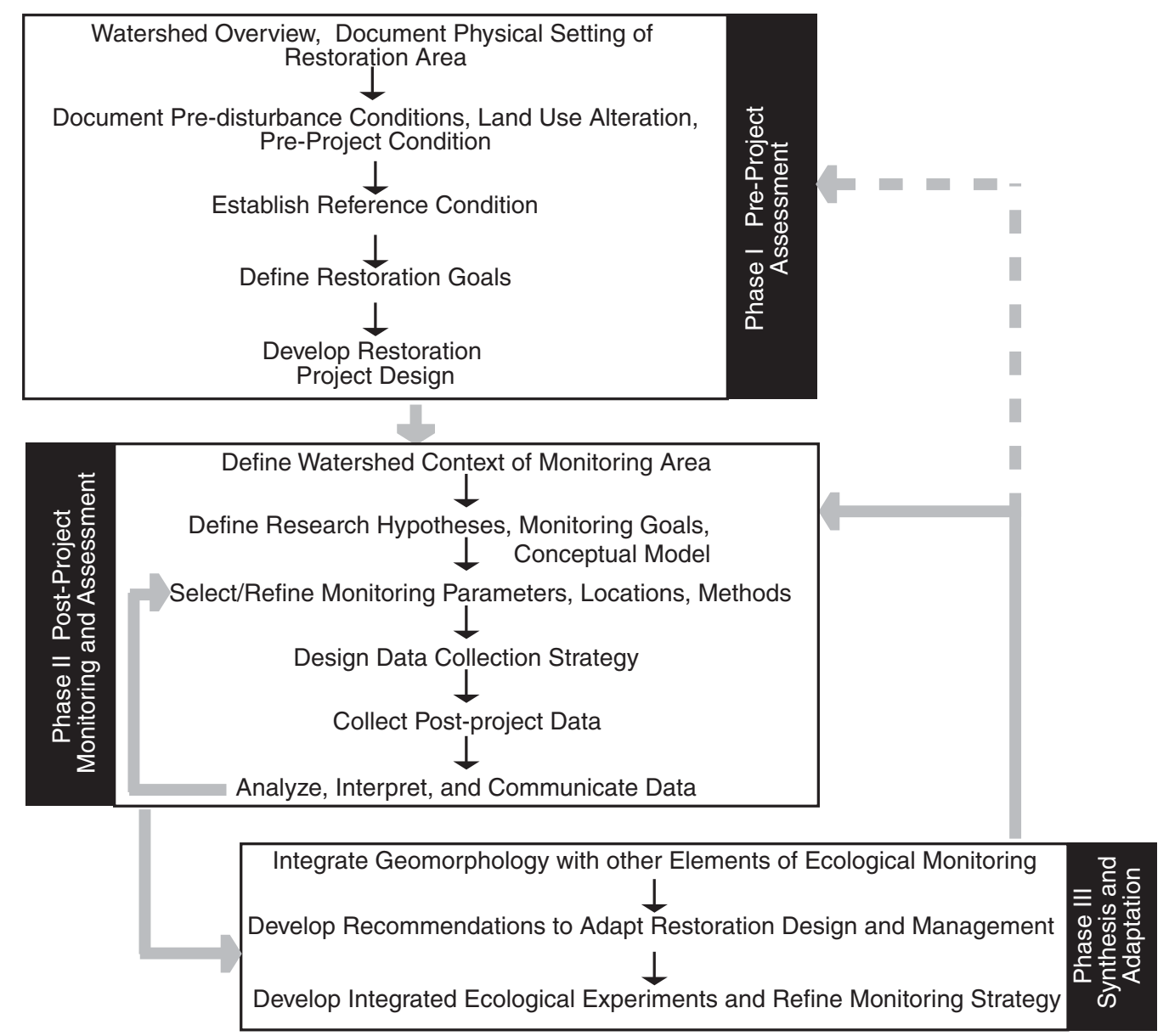

Figure 2. Three-phase adaptive monitoring, assessment and management framework for lowland floodplain rivers. The interior Phase II arrow is the iteration illustrated in this paper. The dashed gray arrow recognizes that some iteration may be necessary between Phases I and II as monitoring and assessment data provide new knowledge to help refine restoration goals 
projects, the Cosumnes River floodplain restoration project design and implementation preceded other assessment elements and the first comprehensive geomorphic studies occurred after the restoration project was implemented. Acknowledging this deviation from the ideal framework, the following sections detail selected elements of the first two phases of the framework using knowledge gained from the Cosumnes River watershed geomorphic investigations as a case study. Phase III elements of the framework are subject to funding constraints and are beyond the scope of this paper, but should be iterative with on-going research.

\section{PHASE I-PRE-PROJECT ASSESSMENT}

\section{Overview of physical setting of restoration area}

The Cosumnes River (basin area $\sim 3000 \mathrm{~km}^{2}$ ) drains the Sierra Nevada and flows southwest across the Central Valley to its confluence with the Mokelumne River upstream of the Sacramento-San Joaquin River Delta (Figure 1). Levees separate the river from its floodplain along most of the lowland reaches - where agriculture is the dominant land use, inhibiting lateral connectivity except during accidental breaches, such as occurred during the 1997 flood (California DWR, 1997). In contrast, longitudinal connectivity from the headwaters to the restoration area at the Cosumnes River Preserve is relatively intact because there are no large dams on the Cosumnes River. Thus, the Cosumnes River has a relatively natural winter rainfall and spring snowmelt hydrograph and still receives annual winter and spring flood pulses, in contrast to adjacent watersheds with multiple large dams that regulate flow. Taking advantage of the opportunity to restore seasonal flooding to portions of the floodplain at the Cosumnes River Preserve, the Cosumnes River Preserve Partners initiated an experimental floodplain restoration program by breaching levees (Figure 3). The first intentional levee breach was constructed in Fall 1995 at the 'Accidental Forest' floodplain. During Fall 1997, a second breach was opened at the upstream 'Corps Breach' floodplain as part of a long-range watershed plan (TNC, 1992; Swenson et al., 2003).

\section{Pre-disturbance geomorphic conditions and land use alteration}

Prior to European settlement, the lower Cosumnes River floodplain ecosystem upstream of the confluence consisted of multiple channels associated with dense riparian forests where inter-channel floodplain islands contained natural levees, splay complexes, seasonal marshes and perennial floodplain lakes (Florsheim and Mount, 2002,

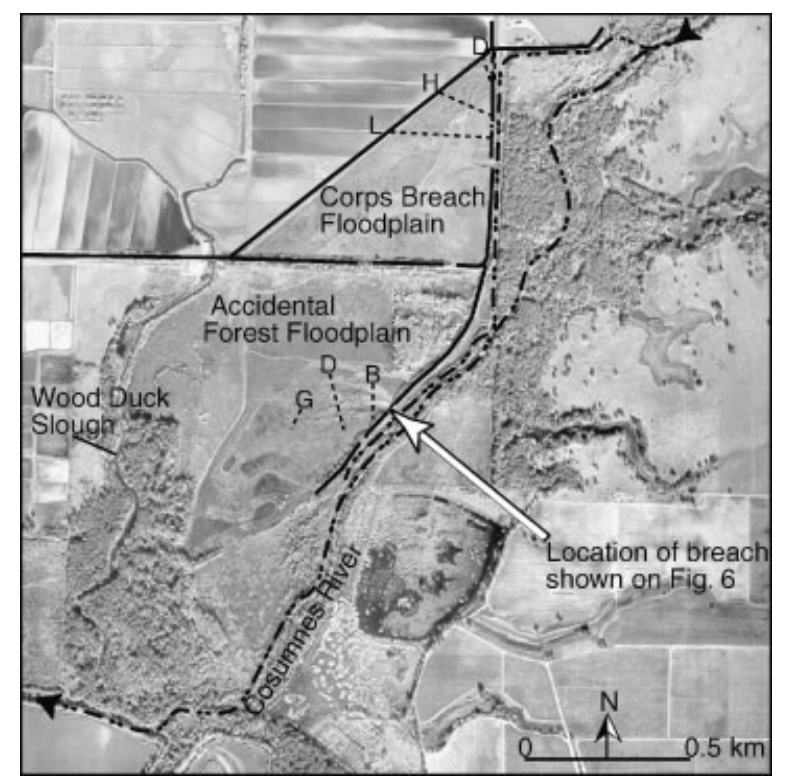

Figure 3. Locations of Corps Breach and Accidental Forest floodplain levee breaches at Cosumnes River Preserve (modified after Florsheim and Mount, 2002) 
2003). These landforms supported a riparian ecosystem that extended across most of the floodplain, and remnants of the once thriving valley oak forest remain along the natural levees of former channels within the Cosumnes River Preserve. Dynamic geomorphic and hydrologic processes such as avulsion, erosion, deposition and seasonal flooding created the natural disturbances that modified and sustained ecosystem attributes in this complex anastomosing river habitat (Florsheim and Mount, 2003).

Extensive levee construction and agricultural leveling during the past century concentrated flow from the multiple channel system into a main channel isolated from its floodplain. Whereas hydraulic mining in the Sierra Nevada and dredging for gold in the lowland riparian zones once increased sediment supply to the study area (Florsheim and Mount, 2003), current aggregate extraction reduces supply. As in other river systems draining the west side of the Sierra Nevada, grazing, timber harvest, riparian forest clearing, floodplain agriculture, woody debris removal, water diversions and urbanization further influence fluvial processes and ecology in the restoration project area (Mount, 1995). The magnitude of change in the annual sediment budget related to these land uses has not yet been documented, but should be addressed in a long-term monitoring framework such as that proposed in this paper.

\section{Post-project assessment of geomorphic conditions}

Although post-project geomorphic data collection falls into Phase II of the assessment framework presented in this paper, we describe these data here in order to provide a basis for understanding the rationale used in developing and refining the framework elements as part of the adaptive assessment process.

Cosumnes River upstream of floodplain restoration area. Comparison of historical topographic data and recent surveys shows that the Cosumnes River between Hwy 16 and Twin Cities Road has undergone 2-3 m of incision since the early 1900s. Recent surveys between the upstream Hwy 16 to Meiss Road reach suggest that channel adjustment has shifted to aggradation, while in the downstream reach between Meiss and Twin Cities Roads the trend of channel-bed lowering persists (Constantine et al., 2003). In both reaches, connectivity between the main Cosumnes River channel and the adjacent floodplain is inhibited. In the upstream aggrading reach, where erosion of unconsolidated coarse sand to cobble-sized alluvial banks contributes sediment to the river, the wide channel and relatively high banks increase channel capacity and minimize floodplain inundation. In the incised reach downstream, the enlarged channel and agricultural levees contain moderate floods within the channel. Where agricultural levees are present, floodplain inundation occurs during accidental breaches or when levees are overtopped. The loss of channel-floodplain connectivity upstream of the restoration project reach is presumed to have an impact on hydrologic, water quality, geomorphic and ecologic conditions within the restoration area.

Another significant effect of incision upstream of the restoration area is the alteration of the self-formed alluvial river morphology into a river that behaves as a rock-controlled channel due to exhumation of indurated duripan layers (Constantine et al., 2003). A knickzone formed by incision into bedrock and duripan separates the aggrading channel bed upstream of Meiss Road from the incised reach downstream (see Figure 2(B) in Constantine et al., 2003). Resistant duripan outcrops, as well as numerous engineered diversion weirs, affect local channel gradient, channel geometry, patterns of sedimentation and pool spacing. In the incised reach (between $18 \mathrm{~km}$ upstream of Wilton and $32 \mathrm{~km} \sim$ Hwy 99), where duripan or erosion control structures increase bank stability, cross-section geometry is characterized by low width to depth ratios. The narrow and deep incised geometry augments the ability of the channel to transfer material downstream and sediment transport achieves equal mobility at or below bankfull discharge, defined as the flow with recurrence interval $\sim 1.5-2.0$ years (Constantine et al., 2003). In this reach, all material supplied is transported downstream regardless of size, with minimal transient sediment storage in bedforms such as riffles. Moreover, the presence of indurated or artificially hardened banks limits sediment supplied from bank erosion in the reach downstream of Meiss Road.

Channel incision and exposure of duripan layers has a significant impact on grain size and sediment transport upstream of the project reach. Longitudinally, the median grain size of the bed sediment follows a fining pattern with a diminution coefficient of $0.072 / \mathrm{km}$ in a $42.8 \mathrm{~km}$ reach downstream of Hwy 16 (Constantine, 2001); however, downstream fining occurs primarily in the reaches upstream and downstream of the incised reach, whereas the incised reach itself functions as a transport reach. Local variation in the fining pattern is due to deposition upstream of low weirs or duripan knickpoints. Based on the work of Constantine (2001), the gravel-sand transition 
is evident in the lower Cosumnes River over a $9 \mathrm{~km}$ long reach between $\sim 30$ and $39.2 \mathrm{~km}$, representing a 10-15 km downstream shift in the gravel-sand transition zone over the past century. While some gravel is present downstream of Twin Cities Road, the bed of the channel primarily consists of sand. Future downstream shifting of the gravel-sand transition may influence the texture of sediment supplied to the Cosumnes River Preserve floodplain restoration site downstream of Twin Cities Road.

Incision in the low-gradient reach of the Cosumnes River channel segment adjacent to the floodplain restoration area at the Cosumnes River Preserve is substantially less than in the reach upstream. In this downstream locale, floodplain inundation occurs frequently in areas where levees are absent. Channel geometry in the main Cosumnes River and in secondary channels adjacent to the floodplain restoration area was surveyed in 1999 and 2000. Channel geometry surveyed several years following the opening of the breaches illustrates the secondary channels that characterize lowland anastomosing rivers (Figure 4). From the relative difference in channel shape upstream versus downstream of the two breaches, we infer that sediment transport onto the floodplain through the intentional breaches affects main stem Cosumnes channel morphology, with sediment eroded from the channel bed upstream and deposited downstream of the two main breaches (Figure 4).

Floodplain restoration area at the Cosumnes River Preserve. Post-project documentation of floodplain processes at two intentional levee breaches at the Cosumnes River Preserve restoration areas were assessed during 1999 and 2000 following moderate flows. Results suggest that sand splay and channel complex development re-established floodplain topography over the previously leveled agricultural fields during the first several years after the breaches were opened. Rapid vertical accretion and scour occurred within the first several years after intentionally breaching the levees. The morphology of the splay complexes is organized as landforms including low-relief lateral levees, lobes and main and secondary channels (see Figures 5-12 in Florsheim and Mount, 2002) with a maximum short-term deposition rate measured on the splay surface of $0.36 \mathrm{~m} / \mathrm{yr}$ and a maximum scour rate

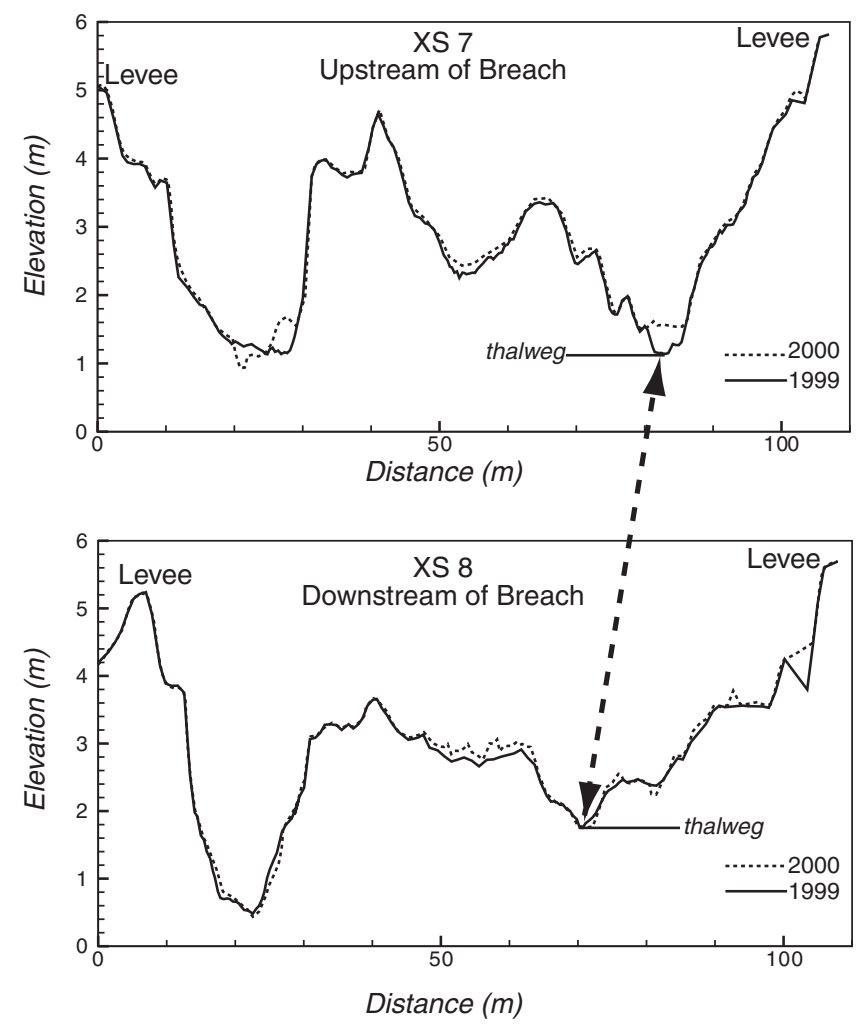

Figure 4. Cross sections surveyed upstream and downstream of the breaches in the main and secondary channels adjacent to the Cosumnes River Preserve illustrate minor changes during water years 1999 and 2000. Example of main Cosumnes channel adjacent to Accidental Forest Breach. The arrow indicates the thalweg segment adjacent to the floodplain restoration area 


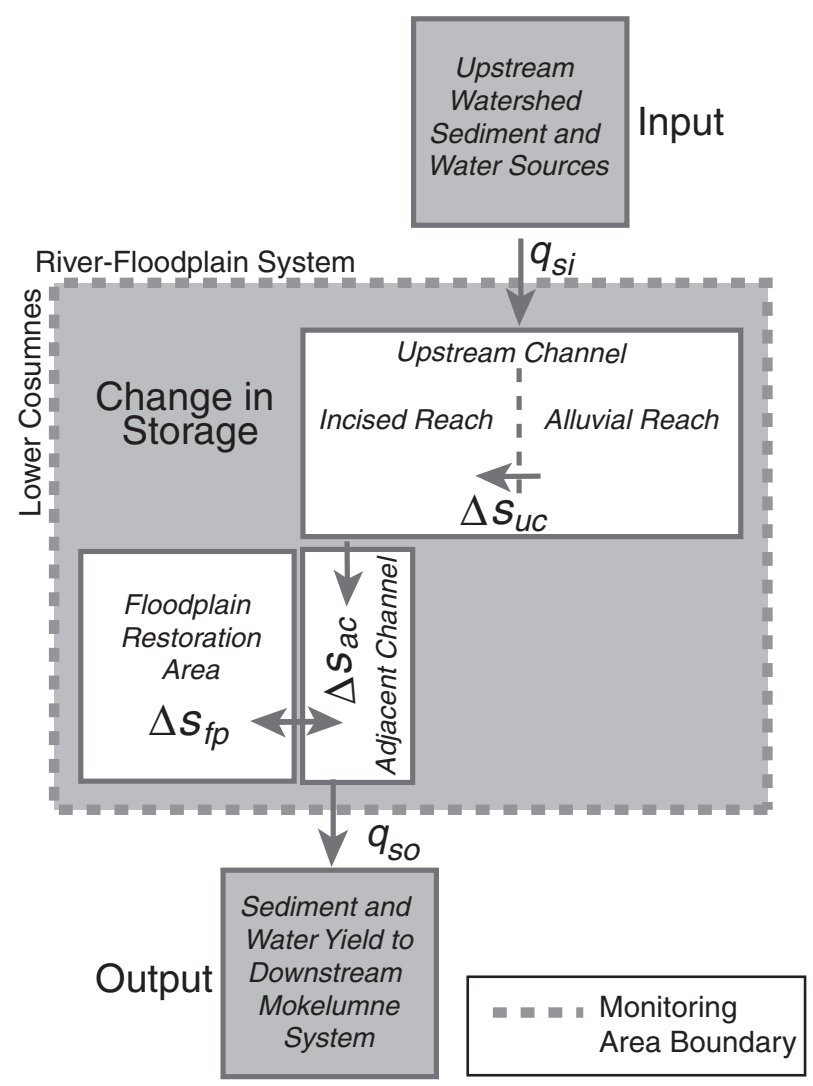

Figure 5. Watershed context of monitoring area and the linkage between the Cosumnes River channel and the downstream Preserve as the rationale for assessment of sediment continuity. The upstream basin is the source area for supply of sediment and the yield of sediment is to the downstream Mokelumne-North Delta system

in channels of $0.27 \mathrm{~m} / \mathrm{yr}$. A scour zone on the floodplain immediately inside the breaches lowered floodplain elevation at the heads of new floodplain channels. Relief became more pronounced over the short-term assessment period as higher magnitude floods scoured channels in the old floodplain sediment and deposited new sand and silt onto the surface of the splay. Juxtaposition of floodplain splay deposition and adjacent channel scour created initial relief ranging from $\sim 1.6$ to $0.25 \mathrm{~m}$, decreasing with distance from the breach. Progradation of main and secondary splay channels takes place by sand transport in the down-floodplain direction, extending topographic variation over the previously level agricultural fields. Additionally, large wood transported onto the floodplain through the breaches promotes local scour and deposition that enhances topographic variability. The new floodplain topography creates variability and is the physical structure of habitat critical for restoration in the previously level agricultural field.

\section{Sediment continuity between the cosumnes channel and floodplain}

The sediment budget relation is a useful tool to assess changes in sediment inflow, storage and yield as well as the geomorphic processes that account for changes over time (Rhoads and Miller, 1990; Reid and Dunne, 1996). Sediment continuity, or the critical linkage between sediment supply, storage and yield in the lowland Cosumnes channel, is illustrated within the watershed context of the Cosumnes River floodplain restoration area (Figure 5). The watershed context promotes flexibility and adaptation of the design to utilize data collected in concurrent sediment monitoring programs in the forested headwaters (MacDonald et al., 2004) or in downstream reaches (Fleenor and Schladow, 2003).

Within the monitoring area, we address changes in stored sediment volume using the sediment budget relation

$$
\Delta S_{\mathrm{uc}}+\Delta S_{\mathrm{ac}}+\Delta S_{\mathrm{fp}}=q_{\mathrm{si}}-q_{\mathrm{so}}
$$


where $\Delta S_{\mathrm{uc}}, \Delta S_{\mathrm{ac}}$ and $\Delta S_{\mathrm{fp}}$ are the changes in sediment storage in the Cosumnes channel upstream, adjacent to and within the restoration area, respectively, $q_{\mathrm{si}}$ is the total volumetric sediment supply rate to the monitoring area upstream of the floodplain restoration area and $q_{\mathrm{so}}$ is the total volumetric sediment outflow from the monitoring area downstream of the Cosumnes River Preserve. To date, geomorphic investigations have provided data used to measure short-term changes in sediment storage at the floodplain restoration area based on field survey data (Florsheim and Mount, 2002) and to infer longer-term changes in the channel-floodplain system based on sediment sampling of Holocene deposits (Florsheim and Mount, 2003). Sediment storage on floodplain sand-splay complexes at the Cosumnes River Preserve restoration area, calculated as the difference between cumulative deposition and scour, was $9445 \mathrm{~m}^{3}$ at the Accidental Forest floodplain (between 1995 and $2000\left(\sim 1890 \mathrm{~m}^{3} / \mathrm{yr}\right)$ ) and $7369 \mathrm{~m}^{3}$ at the Corps Breach floodplain (between 1998 and $2000\left(\sim 2460 \mathrm{~m}^{3} / \mathrm{yr}\right)$ ), during a period with moderate floods (Florsheim and Mount, 2002). In order to balance the sediment budget, both $q_{\mathrm{si}}$ and $q_{\mathrm{so}}$ must also be measured in the future (see Tables II and III for methods). On-going monitoring at the Cosumnes River Preserve will address long-term estimates of floodplain sediment storage rates, $\Delta S_{\mathrm{fp}}$. These rates should be compared with long-term incision rates estimated in the Cosumnes channel upstream of the Preserve, $\Delta S_{\mathrm{uc}}$, in order to test how upstream changes in channel geometry and grain size distributions influence sediment storage volume and texture in the floodplain restoration area. For example, between 1939 and 2000, incision in a $32 \mathrm{~km}$ reach upstream of the Cosumnes River Preserve accounted for roughly $105000 \mathrm{~m}^{3} / \mathrm{yr}$, one part of the total load supplied to downstream reaches. Future changes of a similar magnitude could greatly influence floodplain sediment storage, however, because the upstream channel incised through alluvium to more resistant duripan, current incision rates may be significantly lower.

\section{Reference condition}

Monitoring schemes often define a reference condition, or an undisturbed site, as a comparison to help assess and interpret the magnitude and causes of change documented by the monitoring data. Approaches utilized in other studies include comparisons of (1) upstream to downstream character, (2) an adjacent watershed (Conquest and Ralph, 2001), (3) comparisons based on modeling or (4) pre-disturbance conditions. The concept of a reference condition is a useful measure of the potential of an area to recover (Frissell and Ralph, 2001) and provides a guide to the type of ecosystem attributes that may be restored. However, an upstream-downstream comparison is not a feasible reference condition in the lowland Cosumnes River, because of the disparate nature of the floodplain and adjacent channel system at the Cosumnes River Preserve versus the nature of the floodplain and channel in the upstream incised reach. Moreover, a paired watershed reference approach is not possible because of the Cosumnes River's unique status as the largest unregulated river draining the west side of the Sierra Nevada. For example, while the Cosumnes River's flow regime is sufficient to inundate the lowland floodplain for habitat rehabilitation, dam releases in the neighboring Mokelumne and American River watersheds are regulated to prevent downstream floodplain inundation. Modeling sediment transport using first principles would be a useful tool to test hypotheses; however, data collected during flows when bedload sediment - the size relevant to morphologic change-is in transport are currently lacking. Thus, sediment transport models cannot currently be calibrated, although this approach may be useful in the future as new data are collected. For these reasons, we select the pre-disturbance condition as a reference to understand the dominant processes active in the Cosumnes system prior to changes associated with land use activities. This selection does not imply that the Cosumnes River floodplain will be restored to its pre-disturbance condition. Nor does it imply that all aspects of the system prior to European settlement are representative of potential future evolution. Rather, understanding the dominant processes prior to anthropogenic changes is valuable because it aids our understanding of potential changes at the Cosumnes River Preserve that are possible as constraints such as levees are removed. Analysis of the pre-disturbance, baseline and postproject data helps define the nature of the dominant geomorphic processes necessary to accommodate for sustainable floodplain restoration, namely floodplain inundation, erosion, sedimentation and avulsion. Processes documented at the Cosumnes River Preserve levee break restoration project initially formed sand-splay and channel complexes on the formerly flat farmed field, somewhat mimicking the pre-disturbance morphology. Thus, recognition of the multiple-channel anastomosing character of the pre-disturbance lowland system provides an important model to consider for prediction of future channel-floodplain system adjustment. 


\section{Restoration goals}

The restoration goal defined prior to construction of the intentional breaches at the Cosumnes River Preserve was straightforward: restore hydrologic connectivity between the main Cosumnes River channel and adjacent floodplain in order to promote riparian habitat (TNC, 1992). This goal was based on observations following a levee breach along the lower Cosumnes River in 1985 that resulted in establishment of an 'Accidental Forest,' a patch of cottonwood (Populus fremontii) and several species of willow (Salix), and Oregon ash (Fraxinus latifolia) coincident with sand deposited inside the breach (Swenson et al., 2003). This farmed area, including the Accidental Forest, was added to the Cosumnes River Preserve in 1987 and in effect provided a physical model for habitat creation at the intentional levee breaches. Later work showed that connectivity promoted by the breaches is crucial for supporting native fish use of the floodplain (Crain et al., 2003), and for development of floodplain topography in concert with establishment of riparian forests (Mount et al., 2002), and the restoration goals have evolved in response to acquisition of this new knowledge. As new knowledge is gained through adaptive monitoring and assessment, goals and objectives may be refined to help address specific questions.

\section{PHASE II MONITORING AND ASSESSMENT}

\section{Watershed context of monitoring area}

Identification of watershed-scale hydrologic, geomorphic and ecologic processes that are likely to impact a restoration project helps constrain habitat conditions that can and cannot be reasonably expected. The rationale for selecting geomorphic monitoring parameters requires a systems approach and identification of the appropriate spatial scale over which the dominant processes operate, a challenge recognized by Poudevigne et al. (2002) in restoration projects. In order to address the system scale, we define the Cosumnes watershed context as a nested framework including multiple scales of analysis: a reconnaissance level overview of geomorphic processes that affect the project, more detailed pre-disturbance and current conditions in the vicinity of the project site and in upstream and downstream reaches, and documentation of 'as-built' conditions following project completion.

In the framework outlined in this paper, the monitoring area is defined as both the sand-splay complexes at the floodplain restoration area on the Cosumnes River Preserve and the $52.7 \mathrm{~km}$ of river upstream and adjacent to the project area. This area encompasses the lowland portion of the Cosumnes basin. However, outside of this designated area, upstream or downstream controls on the floodplain restoration project must also be acknowledged. Using results of geomorphic work conducted in the Cosumnes system described in the preceding sections in lieu of a Phase I pre-project assessment, we illustrate how this knowledge may be applied to Phase II monitoring and assessment.

\section{Research hypothesis, monitoring goals, and conceptual model}

The long-term geomorphic monitoring program proposed in this paper would provide data to test the hypothesis that intentional levee breaches restore or rehabilitate geomorphic processes and sediment continuity between the lowland Cosumnes River channel and floodplain restoration area over the long term. Results of initial short-term geomorphic monitoring suggest that sand-splay complexes form the physical structure of new floodplain habitat in the restoration area. Thus, quantifying the change in splay complex sediment storage and the magnitude and duration of the flows that promote sediment continuity is a way to assess restoration of geomorphic processes that create habitat. Critical monitoring goals include (1) determining the magnitude and duration of floods that transport sediment onto the floodplain and (2) documenting and determining the relationship between morphologic changes in the upstream and adjacent Cosumnes River channel and volumetric changes on the splay complexes by collecting data to test the following conceptual model.

Conceptual model. Sediment deposited on lowland river floodplains comprises one component of a river's sediment budget. Three cases may be tested using future monitoring data to assess the influence of sediment continuity on floodplain restoration projects: (A) no change in floodplain sediment storage; (B) a change in floodplain sediment storage without changes in upstream channel stored sediment and $(\mathrm{C})$ a change in floodplain sediment storage with changes in upstream channel stored sediment. Case A would arise if flow stage did not rise to an 
elevation sufficient to enter the breach and inundate the floodplain, if discharge and duration of overbank flow were insufficient to move sand from the head of new floodplain channels and the breaches plugged, or conversely if minimal sediment were supplied from upstream reaches. This case is also possible if there is no net change and sediment input equals sediment output. Case B would occur if sediment contributed to the monitoring area were routed through the upstream channel to the floodplain restoration area without upstream channel erosion or aggradation that alters upstream channel geometry. Case $\mathrm{C}$ might occur during episodes of watershed-scale changes such as fire or widespread land use alteration that initiated geomorphic responses in the lowland portions of river systems. In this case, sediment supply to both the channel and the floodplain restoration area may change. Scenario $\mathrm{B}$ is probable in the Cosumnes system, due to the high transport capacity of the upstream reach incised into resistant duripan layers that retard changes in geometry. Uncertainties arise due to the lag time inherent in the sediment transport process where storage changes in the Cosumnes channel and on the floodplain respond to episodically moving sediment. Further, there may be a lag between geomorphic processes that deposit and erode sediment on the floodplain splay and ecological processes that restore habitat. Testing the research hypothesis, the three cases to assess the influence of sediment continuity on floodplain restoration projects, correlating channel to floodplain changes, and determining the threshold describing the magnitude and duration of floods that transport sediment from the channel to the floodplain is possible through the process-based data collection and analyses described in the following sections.

\section{Monitoring parameters, locations, and methods}

Watershed overview. Because upstream or downstream watershed controls on the floodplain restoration project must be acknowledged, prior to initiating each cycle of the field-monitoring program, a reconnaissance-level watershed overview that identifies changes since the last assessment and review of hydraulic and any sediment records should be conducted. A watershed-scale overview would identify natural and anthropogenic disturbances such as wildfire, large floods or land use changes that greatly alter sediment supply. Watershed reconnaissance should document local levee construction, breaching or removal, addition or removal of bank protection structures, channel or floodplain gravel extraction, changes in agricultural activities, changes in riparian vegetation and conservation and restoration measures, e.g. using GIS, to facilitate detection of changes. For example, new sand splays deposited on floodplains upstream of the restoration area may change sediment supply to the splay complexes. Changes downstream of the monitoring area, such as potential Delta Island rehabilitation or flood control activities that could influence upstream hydrology through modification of baselevel and the backwater effect, must also be documented. A watershed-scale reconnaissance may be accomplished using combined data sources such as remote sensing imagery, field observation and analyses of available data documenting sediment supply, yield or channel and floodplain geometry and hydrology. The effort should be toward assessment of any condition affecting upstream channel geometry and sediment erosion, transport and deposition causing alteration of topography at the floodplain restoration areas.

Monitoring Cosumnes River upstream and adjacent to the floodplain restoration area. Selection of monitoring parameters within the $52.7 \mathrm{~km}$ Cosumnes River reach upstream (Figure 6(A)) and adjacent to (Figure 6(B)) the restoration area is intended to provide data to help understand the influence of channel alteration on the floodplain over time (Table I). Changes in channel morphology, transport capacity, location of the gravel-sand transition and sediment supply and storage will be addressed through geomorphic and topographic mapping, and analysis of repetitive grain size distributions, profile and cross section surveys.

A key parameter to consider in the main Cosumnes River channel is bed elevation, as a metric for one component of the supply that influences floodplain sediment storage. Monitoring future changes in the longitudinal profile, cross sections and topography in incised and non-incised reaches upstream of the Cosumnes River Preserve will afford quantification of the magnitude and rates of change of sediment supply and help our understanding of the role of longitudinal connectivity between the upstream channel and downstream floodplain restoration area. Similarly, monitoring bed elevation adjacent to the floodplain restoration area through repetitive surveys (Figure 6(B)) would illustrate how levee breaches that divert flow and sediment onto the floodplain affect main channel morphology (Table I). Thalweg longitudinal profiles, cross sections and topography will provide data to quantify local changes in channel gradient, aggradation and incision, width to depth ratio and bedform alteration. 


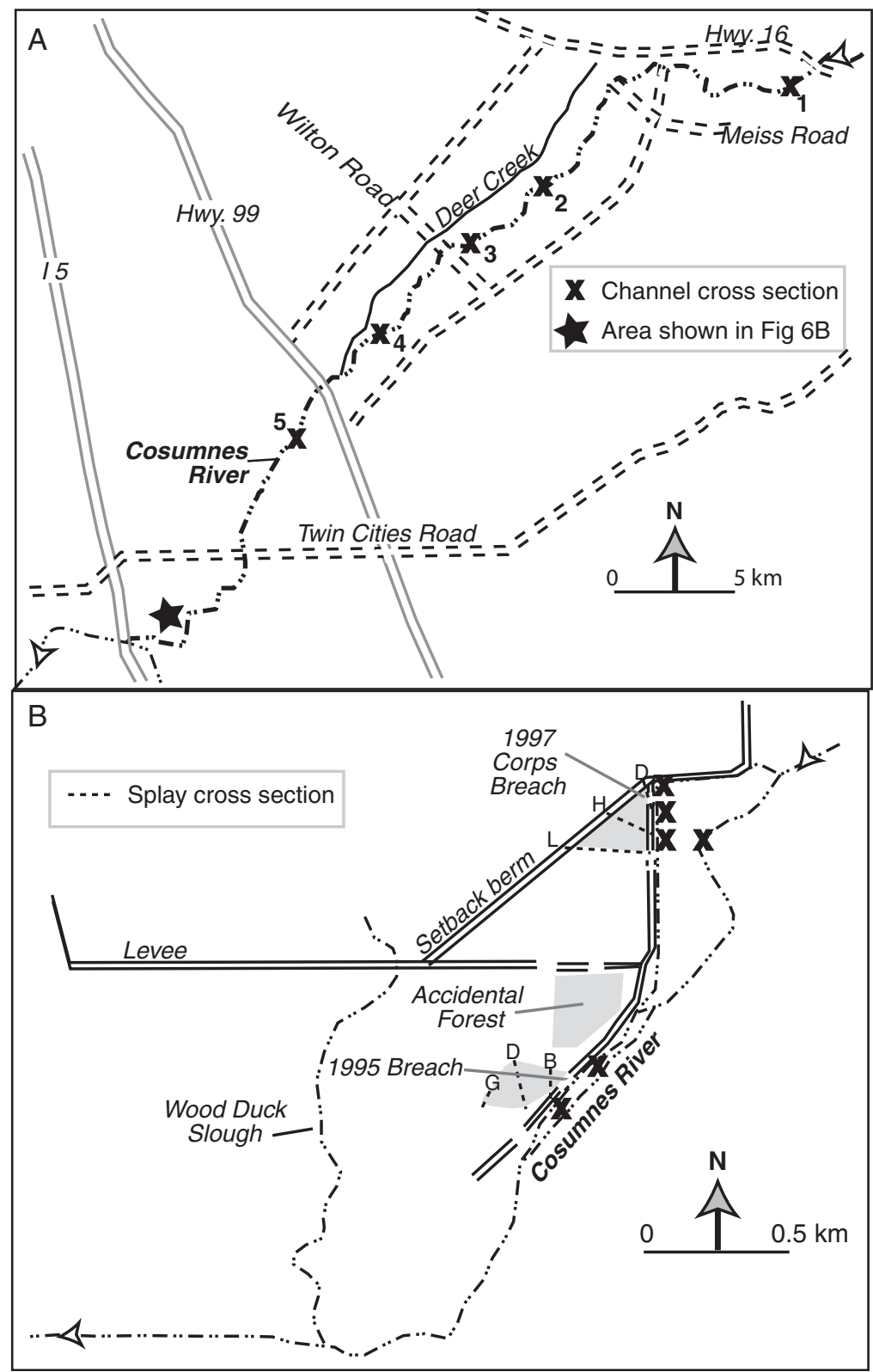

Figure 6. Monitoring sample locations-note different scales on Figures. (A) Cosumnes River channel upstream of floodplain restoration area shows five locations. (B) Cosumnes River Preserve floodplain restoration area and channel adjacent to floodplain restoration area

An additional parameter to document as it accumulates is large woody debris, because debris jams may promote levee breaches and avulsion.

Monitoring the floodplain restoration area. Geomorphic monitoring parameters in the floodplain restoration area are identified in order to aid documentation of long-term changes to sand-splay complexes (Figure 6(B)) formed as a result of the intentional levee breaches (Table II). To date, our geomorphic investigations suggest that future floods that transfer water and sediment onto the floodplain restoration area through the breaches will continue to incise new channels, aggrade lobes and lateral levees, prograde down-floodplain, interact with new riparian vegetation and in general contribute to the physical variability needed to restore floodplain habitat. These changes appear to be evolving with a multiple-channel avulsing character similar to the reference condition, however, 
Table I. Parameters to consider upstream and adjacent to floodplain restoration area

\begin{tabular}{|c|c|c|}
\hline Parameter & Method & Analysis \\
\hline \multirow[t]{2}{*}{ Morphology } & $\begin{array}{l}\text { Low-altitude aerial photo and } \\
\text { geomorphic map }\end{array}$ & Magnitude and frequency of channel planform change \\
\hline & $\begin{array}{l}\text { Surveys: } \\
\text { Longitudinal profile } \\
\text { Channel topography }\end{array}$ & $\begin{array}{l}\text { Changes in geomorphic attributes: } \\
\text { pool to pool spacing, patterns of sedimentation or } \\
\text { scour, riffles, pools, bars, steps, woody debris }\end{array}$ \\
\hline Gradient & $\begin{array}{l}\text { Surveys: } \\
\quad \text { Longitudinal profile }\end{array}$ & Changes in gradient, profile shape (e.g. convexity) \\
\hline Bed elevation & $\begin{array}{l}\text { Surveys: } \\
\text { Longitudinal profile } \\
\text { Cross sections } \\
\text { Sub-reach topography }\end{array}$ & Changes in location and rates of deposition, incision \\
\hline Exposure of duripan & $\begin{array}{l}\text { Surveys: } \\
\quad \text { Longitudinal profile }\end{array}$ & Location and extent of non-alluvial channel structure \\
\hline Channel geometry & $\begin{array}{l}\text { Surveys: } \\
\text { Cross sections }\end{array}$ & Changes in width to depth ratio \\
\hline $\begin{array}{l}\text { Bank erosion and } \\
\text { local sediment supply }\end{array}$ & $\begin{array}{l}\text { Surveys: } \\
\text { Cross sections, erosion pins } \\
\text { Aerial photographs } \\
\text { Field reconnaissance }\end{array}$ & Changes in sediment erosion rate, production volume \\
\hline Grain-size distribution & $\begin{array}{l}\text { Surface and subsurface sediment } \\
\text { samples }\end{array}$ & $\begin{array}{l}\text { Downstream fining, diminution coefficient, } \\
\text { gravel sand transition, sorting, pavement ratio }\end{array}$ \\
\hline Hydrology & $\begin{array}{l}\text { Analysis of USGS gaging station } \\
\text { records (at Michigan Bar) }\end{array}$ & $\begin{array}{l}\text { Discharge }(Q) \text {, flow duration, flood frequency, } \\
\text { changes in timing of flow, rates of change }\end{array}$ \\
\hline $\begin{array}{l}\text { Transport capacity } \\
\text { and shear stress }\end{array}$ & $\begin{array}{l}\text { Surveys: } \\
\text { Longitudinal profile } \\
\text { Cross sections } \\
\text { Grain size sampling }\end{array}$ & $\begin{array}{l}\text { Dimensionless shear stress }\left(\tau^{*}\right) \\
\text { Stream power per unit width }(\omega=\gamma Q S / w)\end{array}$ \\
\hline Large woody debris & Mapping, EDM surveys of topography & Changes in distribution, extent of log jams, wood volume \\
\hline Sediment transport & $\begin{array}{l}\text { Acoustic Doppler current profiler } \\
\text { (ADCP), automated sampler }\end{array}$ & Sediment budget \\
\hline
\end{tabular}

considerable uncertainty exists related to sediment storage and supply from the upstream channel, the influence of newly established vegetation, and local morphologic changes could cause the breaches to plug or become ineffective in transporting water and sediment onto the floodplain. Long-term floodplain monitoring that will help reduce uncertainty related to these questions should include quantification of rates of change in sediment deposition, incision and progradation of the sand-splay and channel complexes. Initial surveys of the sand-splay and channel complexes were conducted during the first years following the breaches when newly established riparian vegetation height was low relative to adjacent levees used as survey bases. With newly established floodplain vegetation thriving, dense patches grow higher than surrounding levees; subsequent surveys will require combinations of field and aerial analyses to assess sedimentation and erosion changes along the original cross section transect lines. Analysis of spectral images, grain size distributions, repetitive surveys and flow and sediment transport measurement data will document rates of sand-splay and channel complex change. Surveys needed to document floodplain erosion and sedimentation include topography of the splay complex with several monumented cross sections and longitudinal profiles of new floodplain channels. Documenting changes in the sand-splay complexes over time requires monitoring geomorphic parameters specific to anastomosing rivers, such as the number of new floodplain channel segments, segment lengths and the density of new floodplain channels within the restoration area, as demonstrated by Florsheim and Mount (2003). Additional methods to document sedimentation are reviewed by Steiger and Gurnell (2003). 


\section{J. L. FLORSHEIM, J. F. MOUNT AND C. R. CONSTANTINE}

Table II. Parameters to consider in floodplain restoration area sand-splay complex

\begin{tabular}{|c|c|c|}
\hline Parameter & Method & Analysis \\
\hline \multirow[t]{3}{*}{$\begin{array}{l}\text { Topography } \\
\text { (morphology and relief) }\end{array}$} & $\begin{array}{l}\text { Low-altitude aerial photo and } \\
\text { geomorphic map }\end{array}$ & $\begin{array}{l}\text { Extent of splay complex, changes in topographic } \\
\text { complexity, changes in elevation and distribution } \\
\text { of new surfaces }\end{array}$ \\
\hline & $\begin{array}{l}\text { Electronic distance meter surveys, EDM: } \\
\text { Topography of sand-splay complexes }\end{array}$ & $\begin{array}{l}\text { Morphology: pattern of sediment deposition and } \\
\text { erosion: scour zone, new floodplain channels, } \\
\text { lobes, lateral levees }\end{array}$ \\
\hline & $\begin{array}{l}\text { Lidar, laser altimetry, SAR } \\
\text { interferometry, or equivalent } \\
\text { spectral method }\end{array}$ & $\begin{array}{l}\text { Relief: height from thalweg of new floodplain } \\
\text { channels to adjacent splay surface } \\
\text { Floodplain elevation relative to main Cosumnes } \\
\text { River channel thalweg elevation }(l)\end{array}$ \\
\hline Breach geometry & $\begin{array}{l}\text { EDM surveys: } \\
\text { Breach cross section, scour } \\
\text { zone topography }\end{array}$ & Evolution of breach geometry, incision, plugging \\
\hline $\begin{array}{l}\text { Floodplain channel } \\
\text { bed elevation }\end{array}$ & $\begin{array}{l}\text { EDM surveys: } \\
\text { Longitudinal profiles } \\
\text { Transects }\end{array}$ & Deposition, erosion, bedforms \\
\hline Floodplain gradient & $\begin{array}{l}\text { EDM surveys: } \\
\text { Longitudinal profiles }\end{array}$ & Gradient, profile shape \\
\hline $\begin{array}{l}\text { Lobe and lateral levee } \\
\text { depositional rate }\end{array}$ & $\begin{array}{l}\text { EDM surveys: } \\
\text { Transects } \\
\text { Topography } \\
\text { Placement of artificial turf mat }\end{array}$ & Deposition, erosion \\
\hline Progradation rate & $\begin{array}{l}\text { EDM surveys: } \\
\text { Transects } \\
\text { Topography }\end{array}$ & Change in extent \\
\hline Grain size distribution & Surface and sub-surface bulk samples & $\begin{array}{l}\text { Spatial variability on surface of splay complex, } \\
\text { layering of strata }\end{array}$ \\
\hline Effect of initial grading & $\begin{array}{l}\text { EDM, surveys: } \\
\text { Transects } \\
\text { Topography }\end{array}$ & Effect of setback berm, excavated pond \\
\hline \multirow[t]{2}{*}{$\begin{array}{l}\text { Flow and sediment } \\
\text { transport onto floodplain }\end{array}$} & Flow velocity and stage recorders & $\begin{array}{l}\text { Flow magnitude }(Q) \text {, depth }(d) \text {, duration }\left(Q_{\text {dur }}\right) ; \\
\text { timing, rate of filling and draining, compare to } \\
\text { upstream gaging station hydrology }\end{array}$ \\
\hline & ADCP, automated sampler & $\begin{array}{l}\text { Sediment budget; sediment concentration or } \\
\text { bedload transport flux }(Q s)\end{array}$ \\
\hline
\end{tabular}

Table III. Percent of time threshold flow is equaled or exceeded: WY1995-2003

\begin{tabular}{lccc}
\hline Threshold & Maximum \% of time & Minimum \% of time & Average \% of time \\
\hline Floodplain connectivity & 44 & 2 & 22 \\
Threshold of sediment transport onto floodplain & 7 & 0 & 3 \\
\hline
\end{tabular}

\section{Data collection strategy}

A science-based monitoring approach should include long-term data collection necessary to address the stated monitoring goals and the (1) natural variability in rates of climate-dependent geomorphic processes that alter floodplain sediment storage, (2) potential lag time between upstream and downstream changes and (3) long-term geomorphic adjustments resulting from global climate change. A continuous long-term geomorphic monitoring 
program would identify critical periods or events responsible for changes in morphology of the Cosumnes River and floodplain; however, such a program would likely be cost prohibitive. Alternatively, monitoring designs often suggest periodic data collection. However, in the Mediterranean climate of California's Central Valley, where episodic conditions could cause such prescriptions to result in either missing important responses if significant events occur between sample dates, or needlessly sampling during ineffective geomorphic events (Kondolf and Micheli, 1995; Downs and Kondolf, 2002). Moreover, watershed erosion thresholds (e.g. that occur when weathered material on hillslopes reaches a critical state) may add large volumes of sediment to fluvial systems during storms no larger than previous events that did not supply appreciable sediment. Such thresholds may confound attempts to predict sediment supply such that predicting future system responses at the initiation of a monitoring program is not possible. However, some direction toward establishing when monitoring data should be collected is necessary. The event-based monitoring threshold defined in the following section is appropriate where connectivity from the channel to the floodplain during overbank flows is of interest.

Data collection design: frequency and timing - when to monitor. In order to optimize the monitoring design for future data collection in the lowland Cosumnes system, we identify thresholds based on the magnitudes and durations of floods that construct and modify the sand-splay and channel complexes at the Cosumnes River Preserve. Moreover, we develop a model to assess the volume of sand deposited on the floodplain. Whereas the importance of both magnitude and duration in quantifying geomorphically effective floods in channels may be quantified using stream power per unit bed area (Costa and O'Connor, 1995), the approach proposed in this paper examines magnitude and duration of overbank flow, thus focusing attention on the transfer of water and sediment from the Cosumnes River channel onto the floodplain.

Flow connectivity and sediment transport thresholds. During the years since 1995 when the first levee was intentionally breached at the Cosumnes River Preserve, a large range of flow magnitudes has occurred from the highest in 1997 to the lowest in 2001 (Figure 7(A)). Initial short-term field observations suggest that the threshold of flow connectivity, $Q_{\mathrm{c}}$, occurs when magnitude exceeds $\sim 23$ to $25.5 \mathrm{~m}^{3} / \mathrm{s}$, or when $Q / Q_{\mathrm{c}}>1$ (Florsheim and Mount, 2002), and that the threshold of sediment transport from the main Cosumnes River channel through the breach onto the floodplain sand-splay complexes occurs at discharges exceeding $\sim 100 \mathrm{~m}^{3} / \mathrm{s}$, or when $Q / Q_{\mathrm{c}} \geq 4$. Flow through the breach must exceed this sediment transport threshold in order to bring new sand onto the floodplain and create floodplain topography formed by the dynamic sand-splay complexes, whereas seasonal connectivity afforded by smaller overbank floods reworks sandy sediment, contributes finer silt and clay and modifies and maintains newly established riparian habitat. These relatively small overbank floods may also transport sand from the main channel to the head of the floodplain scour zone near the breach, where it may be stored until higher floods scour the deposit.

Integration of flow magnitude-duration. The duration of both small overbank and large sedimenttransporting floods is a critical factor contributing to the amount of morphologic adjustment by deposition and progradation of sediment and by incision of new floodplain channels in the splay complex (Figure 7(B) Table III). Whereas water year 1997 had a significantly higher peak discharge than other years, both 1995 and 1998 had a longer or similar duration of flows that exceeded the threshold of sediment transport onto the floodplain (Figure 8(A)). Because both magnitude and duration influence river-floodplain sediment continuity, the combination of these parameters should be considered in determining when monitoring is warranted.

In an effort to quantify a monitoring threshold that combines the influence of discharge and duration, we numerically integrate the flow duration curves (Figure 7(B)) for the discharge intervals corresponding to transport of sediment onto the floodplain, $Q>100 \mathrm{~m}^{3} / \mathrm{s}$ and channel-floodplain flow connectivity, $Q / Q_{\mathrm{c}}>1\left(Q>25.5 \mathrm{~m}^{3} / \mathrm{s}\right.$; Figure 8(B)). Field observations suggest that sediment is added to the floodplain sand-splay complexes during all years when $Q / Q_{\mathrm{c}} \geq 4\left(Q>100 \mathrm{~m}^{3} / \mathrm{s}\right)$, provided that sediment supply is adequate as it was between 1995 and 2000; thus we propose that geomorphic monitoring is warranted in both the Cosumnes channel and in the floodplain restoration area following these relatively high-magnitude events. Smaller floods with $1 \leq Q / Q_{\mathrm{c}} \leq 4(Q$ between 25.5 and $100 \mathrm{~m}^{3} / \mathrm{s}$ ) inundate the floodplain without adding new sand, but have the capability of modifying existing sand in the splay complexes, as occurred between 2001 and 2003-or during rising or falling stages of higher-magnitude flows before or after the sediment transport threshold is crossed. However, geomorphic monitoring may not always be warranted during these small overbank floods unless significant splay modification occurs. We suggest that the integral of the discharge-duration curve should exceed a value of $\sim 1 \times 10^{8} \mathrm{~m}^{3}$ as a 

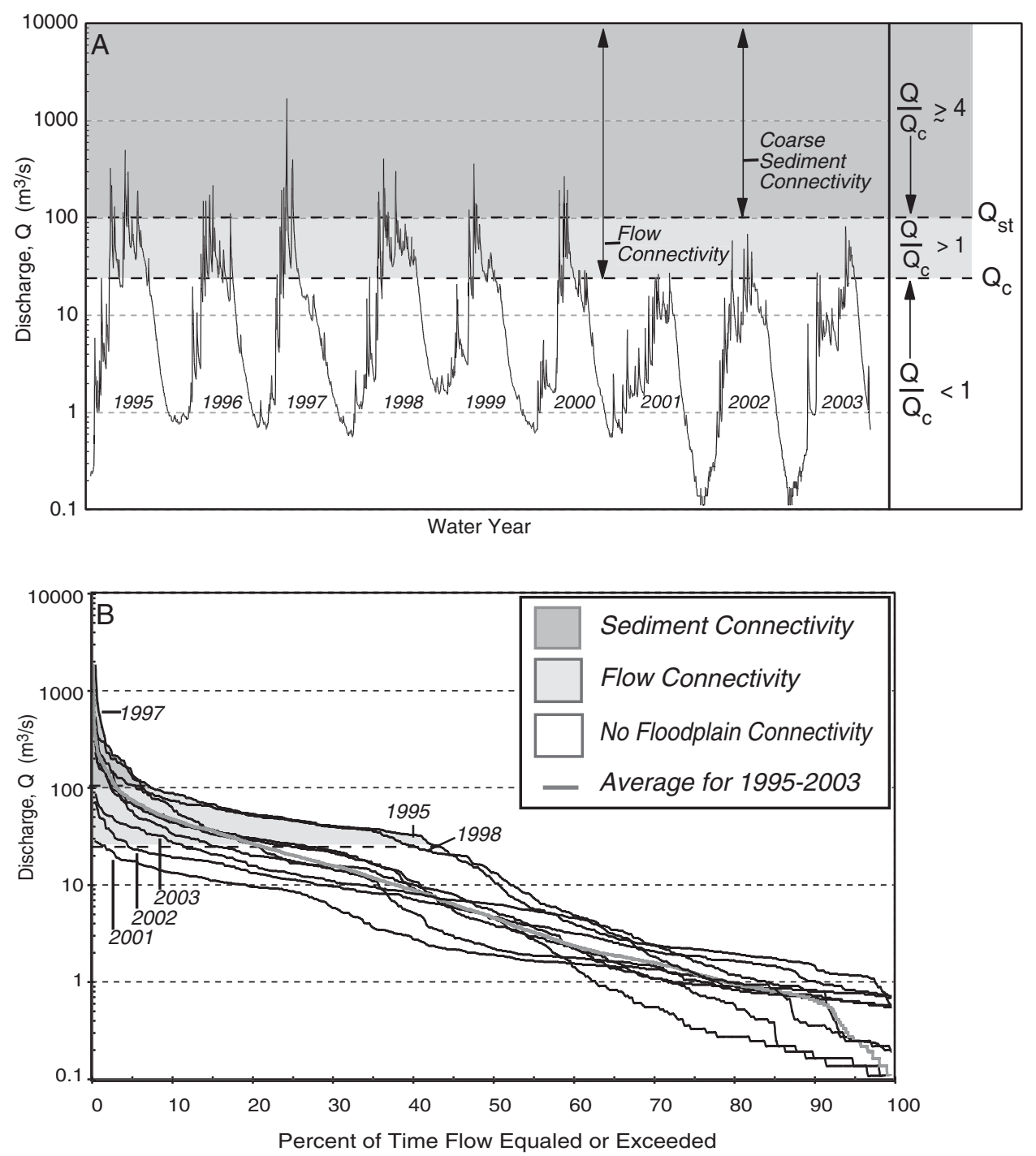

Figure 7. (A) Hydrograph showing flow magnitude during water years 1995-2003. During the period of geomorphic field data collection between 1999 and 2000 annual peak flow recurrence intervals ranged from $\sim 1$ to 3 years. (B) Flow duration curves during water years 1995-2003

trigger to initiate geomorphic monitoring of the sand-splay complex (Figure 8(B)) corresponding to the threshold of continuity $Q / Q_{\mathrm{c}}=1$ as a first estimate of the range of discharge-duration values that cause splay complex modification. Geomorphic monitoring of the sand-splay complexes is not currently warranted when $Q / Q_{\mathrm{c}}<1$ $\left(Q<25.5 \mathrm{~m}^{3} / \mathrm{s}\right)$, regardless of duration, because flow does not inundate the floodplain. However, monitoring changes in cross-section geometry at the levee breaches is warranted, as these lower flows may temporarily deposit sand in the head of floodplain channels previously scoured during higher magnitude events. Moreover, as scour progresses and new channels evolve in the floodplain restoration area, the threshold of connectivity may change. Assessing such factors that influence sediment continuity between the main Cosumnes River and the floodplain through the breaches directly supports the goal of assessing sustainability of the floodplain restoration.

Model to determine floodplain sediment storage volume. A model for sand-splay formation and modification using the criteria defined above may be parametrized and used to predict the volume of sand 

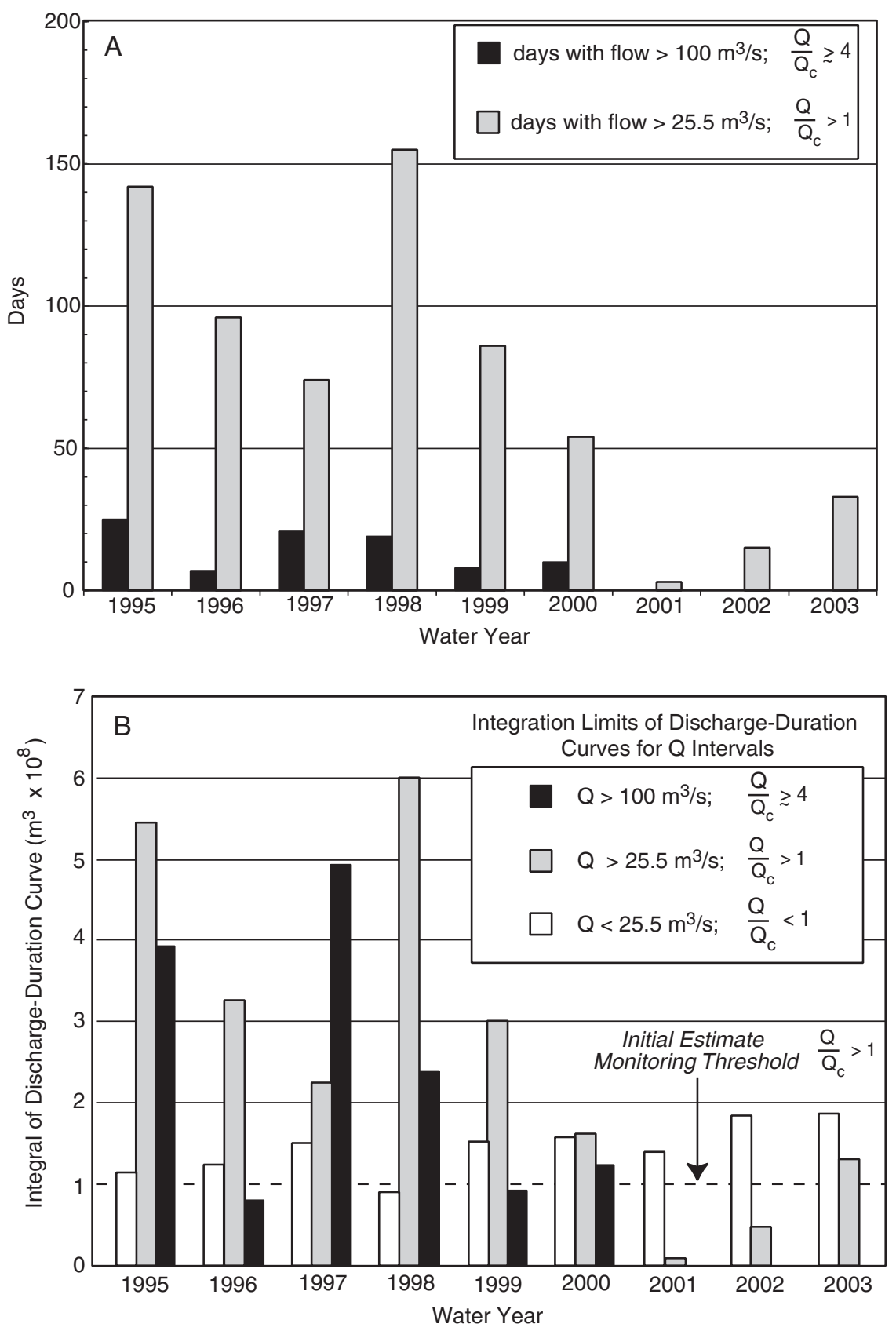

Figure 8. (A) Bar chart showing duration of flows exceeding connectivity threshold and sediment transport onto floodplain threshold. Note that the longest duration of flows exceeding these thresholds does not correspond linearly to the highest magnitude peak flow shown in Figure 7. (B) Bar chart showing integral of discharge duration for limits corresponding to the case of threshold of sediment transport onto floodplain $\left(\sim 100 \mathrm{~m}^{3} / \mathrm{s}\right)$ and the threshold of flow onto floodplain $\left(\sim 25.5 \mathrm{~m}^{3} / \mathrm{s}\right)$. The discharge-duration curve integration yields a value with units of $\mathrm{m}^{3}$ representing the volume of water for each case during each water year

deposited in a sand-splay complex as a basis for comparison to future monitoring data. The volume of sand deposited, $V_{\mathrm{s}}$, is given by

$$
V_{\mathrm{s}}=\Delta Q C_{\mathrm{s}} \Delta t
$$

where $\Delta Q$ is discharge, $C_{\mathrm{s}}$ (here in units of $\mathrm{m}_{\text {sand }}^{3} / \mathrm{m}_{\text {water }}^{3}$ ) is concentration of sand entrained in flow entering the breach and $\Delta t$ is the duration. To date, no direct measurements of $C_{\mathrm{s}}$ for sand, the primary constituent of the 
sand-splay complexes, are available. However, an estimate may be calculated from the equation above using water year 2000 field measurements of $V_{\mathrm{s}}$ equal to $2140 \mathrm{~m}^{3}$ and $5270 \mathrm{~m}^{3}$ at the Accidental Forest and Corps Breach splay complexes, respectively (Florsheim and Mount, 2002). Gaging station data is used to calculate $\Delta Q \Delta t$ above the sediment transport threshold onto the floodplain as $1.4 \times 10^{8} \mathrm{~m}^{3}$, thus $C_{\mathrm{s}}$ is estimated as $1.6 \times 10^{-5} \mathrm{~m}_{\text {sand }}^{3} / \mathrm{m}_{\text {water }}^{3}$ at the Accidental Forest breach and $3.9 \times 10^{-5} \mathrm{~m}^{3}$ sand $/ \mathrm{m}^{3}$ water at the Corps Breach during water year 2000. Using these calculated values of $C_{\mathrm{s}}$, approximations of the volume of sediment deposited in the floodplain sand splay complexes each year since the levee breaches show short-term variability (Figure 9). Whereas differences between predicted and measured data indicate uncertainty in reliance on short term data and in volumetric estimation for years prior to detailed surveys in 1999-2000, trends are distinct. These relations may be used as the basis for a rating curve to predict when the volume of sand deposition on the splay complexes during future floods warrants initiation of geomorphic monitoring activities.

Empirical estimates of $C_{\mathrm{s}}$ are useful because of the difficulty of measuring coarse sediment (sand) transport through the breaches onto the floodplain during flood events; however, the majority of sand that enters the breaches is deposited in the splay complexes where it can be subsequently measured. In contrast, concentrations of silt and clay suspended in flow may be more readily measured during flood events; however, this fine material may be transported onto the floodplain beyond the splay or may even exit the floodplain restoration area with receding flows. $C_{\mathrm{s}}$, the concentration of sand entrained in flow entering the breach, may be measured directly or approximated through several metrics including $\Delta S$, net volumetric changes in storage over the entire splay complex, change in relief between the highest and lowest portions areas of individual cross sections or between depositional areas and incised areas, cross section scour and fill, or changes in floodplain extent (Table II). Future monitoring data collection and analyses will refine the relationship between flow magnitude, duration, sediment supply to the floodplain and geomorphic change. Sediment supply to the floodplain restoration area may be estimated in the future through monitoring of the upstream Cosumnes channel. This model is applicable locally, but may also be applied to other lowland river restoration projects.

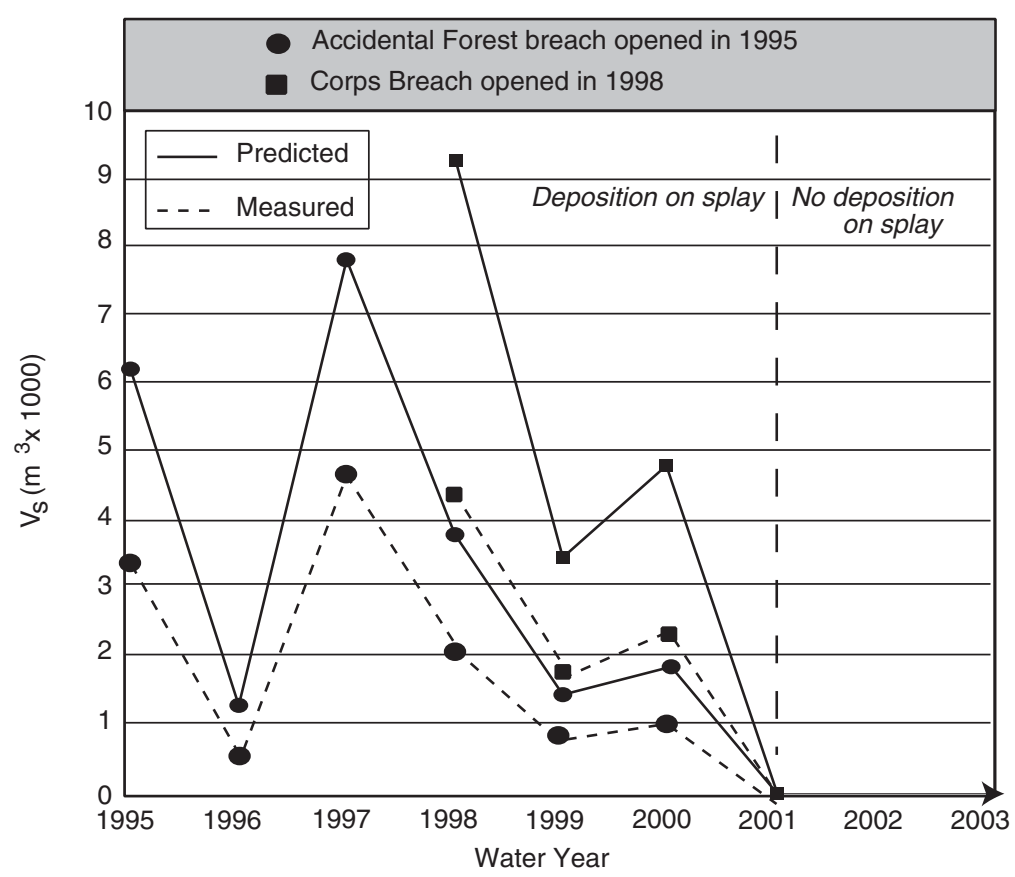

Figure 9. Volume of sand deposited in sand-splay complexes, $V_{\mathrm{s}}$, predicted (solid lines) and measured (dashed lines). Minimal new sediment was contributed to the splays between 2000 and 2003. Predicted volume uses sand concentration, $C_{\mathrm{s}}$, calculated based on short-term (1999 and 2000) field data, measured data includes results of sampling (Florsheim and Mount, 2003) to infer volume changes between the time the breach was opened and 2003 


\section{Data analysis, interpretation and communication}

The final component of the assessment framework includes analysis, interpretation and communication of monitoring results. Consistent data collection formats and analysis methods are critical in order to compare monitoring results over the long term (Statzner et al., 1994). At the same time, flexibility in applying new technology as it is developed is essential. Thus, we propose that monitoring data collection designs and the type of assessment conducted also be adapted as new questions arise, and as warranted to improve data interpretation; it is imperative that the monitoring design itself be scrutinized in order to generate recommendations for updated methods during future monitoring cycles. These refinements will help collect appropriate data to test hypotheses. This will require a long-term institutional commitment to monitoring, data analysis, interpretation and communication. One aspect of communication should include written updates reporting status, trends and a comparison to post-project conditions following each monitoring cycle. The monitoring goals defined in this paper are likely to evolve as new data are collected, analyzed and interpreted, as geomorphic data are integrated with other components of ecosystem assessment and as new research and management questions arise.

\section{DISCUSSION}

In this paper, we propose monitoring assessment methods needed to understand geomorphic changes that occur as dynamic floodplain systems evolve following restoration efforts. Data collected at the Cosumnes River Preserve floodplain restoration project provide a case study to illustrate the rationale for utilizing sediment continuity, or the longitudinal, lateral and vertical transfers of sediment between channels and floodplains during various flood magnitudes over time, as the conceptual model underlying the monitoring and assessment framework. New floodplain channel creation and avulsion, or floodplain sediment-vegetation interactions identified through monitoring and adaptive assessment, should initiate refinement of the monitoring design as the former agricultural field, once separated from the river by levees, evolves toward a connected floodplain-channel ecotone.

Development of metrics to assess restoration of dynamic processes and morphology must address the magnitude and duration of flows and the changes in sediment storage on the floodplain responsible for creation and maintenance of floodplain topography that forms physical structure that promotes biodiversity. As hydrogeomorphic changes become apparent through analysis and interpretation of data, they may then be used to inform and refine restoration science and management.

In order to address the monitoring goals it is critical to determine the magnitude and duration of floods that transport sediment onto the floodplain, and to document changes and determine the relationship between morphologic changes in the channel of the Cosumnes River and the floodplain restoration area. Hydrogeomorphic metrics that may be used to assess sediment transfer from the channel to the floodplain include (1) the ratios of storm discharge to the threshold of connectivity from the main channel onto the floodplain, where connectivity occurs when $Q / Q_{\mathrm{c}}>1$ and sediment transfer from the main channel to the floodplain occurs when $Q / Q_{\mathrm{c}} \geq 4$, (2) the integration of flow magnitude and duration threshold where the preliminary value of $\sim 1 \times 10^{8} \mathrm{~m}^{3}$ corresponds to the threshold of continuity $Q / Q_{\mathrm{c}}=1$ as a first approach toward estimating the range of discharge-duration values that account for significant changes to the splay complexes and (3) the change in volume of sediment stored on the floodplain splay complexes where $V_{\mathrm{s}}=\Delta Q C_{\mathrm{s}} \Delta t$.

These assessment tools were developed using Cosumnes River data as a case study, but they may be applied to other river-floodplain restoration efforts because the hydrogeomorphic assessment of magnitude-duration of overbank flows that change sediment stored on the floodplain, whether through a breach or via overbank flow where a levee is setback or removed, is relevant even if the resulting form is not a sand splay due to the resulting change in the floodplain's physical structure and coincident habitat changes. Thus, the metrics together with the assessment framework proposed in this paper may be applied broadly to a range of adaptive monitoring, assessment and management objectives in California's Central Valley or in other lowland systems.

Quantifying various components of sediment storage within the Cosumnes system addresses effects of longitudinal and lateral continuity between upstream and downstream reaches and between the channel and floodplain. 
Of particular importance to the sustainability of the floodplain restoration is sediment continuity between the main Cosumnes River and the floodplain through the breaches. The proposed monitoring methods are subject to limitations identified by MacDonald (2000) that include difficulty in detecting changes through monitoring, and lag times between project implementation and ecosystem response. Such limitations may be addressed through assessment and analysis of monitoring data that leads to adaptation of monitoring methods or refinement of monitoring goals.

Finally, Phase III of the adaptive framework is intended to facilitate future interdisciplinary integration with other aspects of ecological monitoring through focused experiments and iterative adaptive science, assessment and management. Long-term monitoring data should be analyzed and interpreted in order to develop recommendations to adapt restoration design and management and to refine monitoring strategy, if appropriate. These data would form the basis of integrated ecological experiments to address uncertainties and to gain new insight into dynamic floodplain systems that will further restoration science.

\section{CONCLUSIONS}

We propose a three-phase adaptive assessment framework that may be applied broadly to lowland rivers. Although specific to geomorphic monitoring, this framework could be adapted to other facets of project monitoring and assessment to integrate ecosystem science in lowland rivers. In this paper, we present a conceptual model for evaluating sediment continuity between a river channel and an adjacent floodplain restoration area using the Cosumnes River floodplain restoration project as a case study. We identify flow magnitude-duration thresholds associated with sediment transfer from the main river channel to the floodplain as an example to aid decisions for when to initiate monitoring activities. Additionally, we develop a quantitative model to predict the volume of sediment deposition in floodplain sand splay complexes in an evolving restoration area. Results from the Cosumnes River Preserve case study suggest that all flows with $Q / Q_{\mathrm{c}} \geq 4$ are capable of transporting sand onto the floodplain and splay geomorphology and monitoring is warranted following such events. When $Q / Q_{\mathrm{c}}>1$ flow inundates the floodplain restoration area and is capable of modifying sand already in the sand-splay complexes. As a first approximation, only flows with the integral of the discharge-duration curve greater than $1 \times 10^{8} \mathrm{~m}^{3}$ warrant monitoring at the Cosumnes floodplain restoration area.

Addressing the watershed context in restoration monitoring designs that focus on smaller portions of the watershed is critical in assessment of anabranching lowland systems, where former channel segments are currently separated from the channel by levees, or where meandering systems are narrowed-both common occurrences in developed areas globally. Thus, effective monitoring and management depends on looking outside the constraints of the modern system in order to predict processes likely to occur after constraints are removed-e.g. avulsion and switching of channel location in anabranching systems. These processes unique to lowland rivers highlight the rationale for not directly transferring monitoring and adaptive assessment designs developed for other river environments to assess changes following lowland river restoration efforts.

Hydrogeomorphic processes are one component of the overall monitoring required to test ecosystem habitat restoration goals. Documentation of dominant geomorphic processes prior to disturbances is critical since these processes may re-establish in the absence of constraints, such as levees that are breached or removed as part of the restoration design. The overall monitoring and assessment framework presented in this paper is relevant to habitat restoration and integrated ecological research in lowland rivers with floodplains and can serve as a mechanism to facilitate communication in this and other interdisciplinary studies on lowland river systems in California's Central Valley or in other lowland environments.

\section{ACKNOWLEDGEMENTS}

We thank the UC Davis Cosumnes Research Group and The Nature Conservancy for their assistance, logistical support and insight. We greatly appreciate critical comments from Peter Downs, Lee MacDonald and Greg Pasternack and review from Curt Oldenburg that improved this paper. This project received initial funding from 
the David and Lucile Packard Foundation Conservation Program (1998-3584) and the CALFED Bay-Delta Ecosystem Restoration Program (99NO6).

\section{REFERENCES}

Amoros C, Roux AL, Reygrobellet JL, Bravard JP, Pautou G. 1987. A method for applied ecological studies of fluvial hydrosystems. Regulated Rivers: Research and Management 1: 17-36.

Bayley PB. 1991. The flood pulse advantage and the restoration of river-floodplain systems. Regulated Rivers: Research and Management 6: 75-86.

Bedford BL. 1996. The need to define hydrologic equivalence at the landscape scale for freshwater wetland mitigation. Ecological Applications 6(1): 57-68.

Bravard JP, Amoros C, Pautou G. 1985. Impact of civil engineering works on the successions of communities in a fluvial system. Oikos 47: 92-111.

Brookes A. 1996. Floodplain restoration and rehabilitation. In Floodplain Processes, Anderson MG, Walling DE, Bates PD (eds). Wiley: New York; 553-576.

Brown AG. 1996. Floodplain paleoenvironments. In Floodplain Processes, Anderson MG, Walling DE, Bates PD (eds). Wiley: New York; 95138.

CALFED. 1998. Strategic Plan for the Ecosystem Restoration Program. Prepared by the Strategic Plan Core Team for the CALFED Bay-Delta Program. Sacramento, CA.

California Department of Water Resources (DWR). 1997. Levee Breaks Along the Cosumnes River, January 1997 Flood, Video.

Conquest LL, Ralph SC. 2001. Statistical design and analysis considerations for monitoring and assessment. In River Ecology and Management Lessons from the Pacific Coastal Ecoregion, Naiman RJ, Bilby RE (eds). Springer: Berlin; 455-475.

Constantine CR. 2001. The Effects of Substrate Variability and Incision on the Downstream Fining Pattern in the Cosumnes River, Central Valley, CA, Masters Thesis, UC Davis.

Constantine CR, Mount JF, Florsheim JL. 2003. Effects of longitudinal differences in gravel mobility on the downstream-fining pattern in the Cosumnes River, California. Journal of Geology 111: 233-241.

Costa JE, O’Connor JE. 1995. Geomorphically effective floods. In Natural and Anthropogenic Influences in Fluvial Geomorphology, Costa JE, Miller AJ, Potter KW, Wilcock PR (eds). Geophysical Monograph 89: 45-56.

Crain P, Whitener K, Moyle P. 2003. Use of a restored central California floodplain by larvae of native and alien fishes. In Early Life History of Fishes in the San Francisco Estuary and Watershed. Proceedings of the American Fisheries Society Symposium 39, Feyrer F, Brown LR, Brown RL, Orsi JJ (eds). Bethesda, MD; 125-140.

Downs PW, Kondolf GM. 2002. Post-project appraisals in adaptive management of river channel restoration. Environmental Management 29(4): 477-496.

Fleenor WE, Schladow SG. 2003. Sediment Flux Variation in Two Central Valley Rivers, CALFED Science Conference, 2003, Sacramento, CA; 203.

Florsheim JL. 2004. Side-valley tributary fans in high-energy river floodplain environments: sediment sources and depositional processes, Navarro River Basin, California. Geological Society of America, Bulletin 116(7/8): 923-937.

Florsheim JL, Mount JF. 2002. Restoration of floodplain topography by sand-splay complex formation in response to intentional levee breaches, lower Cosumnes River, California. Geomorphology 44(1/2): 67-94.

Florsheim JL, Mount JF. 2003. Changes in lowland floodplain sedimentation processes: pre-disturbance to post-rehabilitation, Cosumnes River, California. Geomorphology 56: 305-323.

Frissell CA, Ralph SC. 2001. Stream and watershed restoration. In River Ecology and Management Lessons from the Pacific Coastal Ecoregion, Naiman RJ, Bilby RE (eds). Springer: Berlin; 599-624.

Galat DL, Fredrickson LH, Humburg DD, Bataille KJ, Bodie JR, Dohrenwend J, Gelwicks GT, Havel JE, Helmers DL, Hooker JB, Jones JR, Knowltron MF, Kubisiak J, Mazourek J, McColpin AC, Renken RB, Semlitsch RD. 1998. Flooding to restore connectivity of regulated, large-river wetlands. BioScience 48(9): 721-733.

Gurnell AM. 1995. Vegetation along river corridors: hydrogeomorphological interactions. In Changing River Channels, Gurnell A, Petts G (eds). Wiley: New York; 237-260.

Holling CS. 1978. Adaptive Environmental Assessment and Management. Wiley: London.

Hupp CR, Osterkamp WR. 1996. Riparian vegetation and fluvial geomorphic processes. Geomorphology 14: $277-295$.

Irwin LL, Wigley TB. 1993. Toward an experimental basis for protecting forest wildlife. Ecological Applications 3(2): $213-217$.

Junk WJ, Bayley PB, Sparks RE. 1989. The flood pulse concept in river-floodplain systems. In Proceedings of the International Large River Symposium, Dodge DP (ed.). Canadian Special Publications Fisheries and Aquatic Sciences 106: 110-127.

Kondolf GM, Micheli EM. 1995. Evaluating stream restoration projects. Environmental Management 19: 1-15.

MacDonald LH. 2000. Evaluating and managing cumulative effects, processes and constraints. Environmental Management 26(3): 299-315.

MacDonald LH, Coe D, Litschert S. 2004. Assessing cumulative watershed effects in the Central Sierra Nevada: hillslope measurements and catchment-scale modeling. In Proceedings of the Sierra Nevada Science Symposium, PSW_GTR-193, Murphy DD, Stine PA (eds). Kings Beach, CA: Forest Service, USDA. 


\section{J. L. FLORSHEIM, J. F. MOUNT AND C. R. CONSTANTINE}

MacDonald LH, Smart AW, Wissmar RC. 1991. Monitoring Guidelines to Evaluate Effects of Forestry Activities on Streams in the Pacific Northwest and Alaska, Center for Streamside Studies EPA 910/0-91-001.

Marston RA, Girel J, Pautou G, Piegay H, Bravard JP, Arneson C. 1995. Channel metamorphosis, floodplain disturbance, vegetation development: Ain River, France. Geomorphology 13: 121-131.

Montgomery DR, Buffington JM. 1997. Channel reach morphology in mountain drainage basins. Geological Society of America Bulletin 109: 596-611.

Montgomery DR, MacDonald LH. 2002. Diagnostic approach to stream channel assessment and monitoring. Journal of the American Water Resources Association 38(1): 1-16.

Mount JF. 1995. California Rivers and Streams. University of California Press, Berkeley, CA.

Mount JF, Florsheim JL, Trowbridge WB. 2002. Restoration of dynamic floodplain topography and riparian vegetation establishment through engineered levee breaching. Proceedings: The Structure, Function and Management Implications of Fluvial Sedimentary Systems, IAHS Publication No. 276; 85-91.

Nanson GC, Croke JC. 1992. A genetic classification of floodplains. Geomorphology 4: 459-486.

O'Connor JE, Jones MA, Haluska TL. 2002. Flood plain and channel dynamics of the Quinault and Queets Rivers, Washington, USA. Geomorphology 51: 313-359.

Palmer MA, Bernhardt ES, Allan JD, Lake PS, Alexander G, Brooks S, Carr J, Clayton S, Dahm CN, Shah JF, Galat DL, Loss SG, Goodwin P, Hart DD, Hassett B, Jenkinson R, Kondolf GM, Lave R, Meyer JL, O’Donnell TK, Pagano L, Sudduth E. 2005. Standards for ecologically successful river restoration. Journal of Applied Ecology 42(2): 208-217.

Parma AM, NCEAS Working Group on Population Management. 1998. What can adaptive management do for our fish, forests, food and biodiversity. Integrative Biology 1: 16-26.

Petts GE. 1990. The role of ecotones in aquatic landscape management. In The Ecology and Management of Aquatic Terrestrial Ecotones. Man and the Biosphere Series 4, Naiman RJ, Decamps H (eds). UNESCO: Paris; 227-261.

Petts GE, Large ARG, Greenwood MT, Bickerton MA. 1992. Floodplain assessment for restoration and conservation: linking hydrogeomorphology and ecology. In Lowland Floodplain Rivers: Geomorphological Perspectives, Carling PA, Petts GE (eds). Wiley: New York; 217-234.

Pinay G, Decamps H, Chauvet E, Fustec E. 1990. Functions of ecotones in fluvial systems. In The Ecology and Management of Aquatic Terrestrial Ecotones. Man and the Biosphere Series 4, Naiman RJ, Decamps H (eds). UNESCO: Paris; 141-169.

Poff NL, Allan JD, Bain MB, Karr JR, Prestegaard KL, Richter BD, Sparks RE, Stromberg JC. 1997. The natural flow regime: a paradigm for river conservation and restoration. BioScience 47: 769-784.

Poudevigne I, Alard D, Leuven RSEW, Nienhuis PH. 2002. A systems approach to river restoration: a case study in the lower Seine Valley, France. River Research and Applications 18(3): 239-247.

Reid LM, Dunne T. 1996. Rapid Evaluation of Sediment Budgets. GeoEcology Catena. Verlag GMBH: Reiskirchen, Germany.

Rhoads BL, Miller MV. 1990. Impact of riverine wetlands construction and operation on stream channel stability: conceptual framework for geomorphic assessment. Environmental Management 14(6): 799-807.

Richards K, Brasington J, Hughes F. 2002. Geomorphic dynamics of floodplains: ecological implications and a potential modeling strategy. Freshwater Biology 47(4): 559-579.

Richards K, Chandra S, Friend P. 1993. Avulsive channel systems: characteristics and examples. In Braided Rivers: Geological Society Special Publication 75, Best JL, Bristow CS (eds); 195-203.

Richter BD, Baumgartner JV, Wigington R, Braun DP. 1997. How much water does a river need? Freshwater Biology 37: $231-249$.

Schnitzler A, Hale BW, Alsum E. 2005. Biodiversity of floodplain forests in Europe and eastern North America: a comparative study of the Rhine and Mississippi Valleys. Biodiversity and Conservation 14: 97-117.

Slingerland R, Smith ND. 2004. River avulsions and their deposits. Annual Reviews of Earth and Planetary Sciences 32: 257-285.

Smith ND, Cross TA, Dufficy JP, Clough SR. 1989. Anatomy of an avulsion. Sedimentology 36: 1-23.

Sparks RE, Bayley PB, Kohler SL, Osborne LL. 1990. Disturbance and recovery of large floodplain rivers. Environmental Management 14(5): 699-709.

Sparks RE, Nelson JC, Yin Y. 1998. Naturalization of the flood regime in regulated rivers. BioScience 48(9): 706-720.

Stanford JA, Ward JV. 2001. Revisiting the serial discontinuity concept. Regulated Rivers: Research and Management 17: 303-310.

Stanford JA, Ward JV, Liss WJ, Frissell CA, Williams RN, Lichatowich JA, Coutant CC. 1996. A general protocol for restoration of regulated rivers. Regulated Rivers: Research and Management 12: 391-413.

Statzner B, Resh VH, Roux AL. 1994. The synthesis of long-term ecological research in the context of concurrently developed ecological theory: design of a research strategy for the Upper Rhone River and its floodplain. Freshwater Biology 31: 253-263.

Steiger J, Gurnell AM. 2003. Spatial hydrogeomorphological influences on sediment and nutrient deposition in riparian zones: observations from the Garonne River, France. Geomorphology 49(102): 1-23.

Swenson RO, Whitener K, Eaton M. 2003. Restoring floods to floodplains: riparian and floodplain restoration at the Cosumnes River Preserve. In California Riparian Systems: Processes and Floodplain Management, Ecology, Restoration, 2001 Riparian Habitat and Floodplains Conference Proceedings, Faber PM (ed.). Riparian Habitat Joint Venture: Sacramento, CA; 224-229.

The Bay Institute of San Francisco (TBI). 1998. Sierra to the Sea: the Ecological History of the San Francisco Bay-Delta Watershed. San Francisco, CA, I-IV. http://www.bay.org/Pubs/STSall.pdf

The Nature Conservancy (TNC). 1992. Cosumnes River Watershed Project Strategic Plan. The Nature Conservancy of California Report, Cosumnes River Preserve, CA.

Thorne CR. 2002. Geomorphic analysis of large alluvial rivers. Geomorphology 44: 203-219. 


\section{ADAPTIVE ASSESSMENT TECHNIQUE FOR LOWLAND RIVERS}

Tockner K, Stanford J. 2002. River floodplains: present state and future trends. Environmental Conservation 29(3): 308-330.

Walters CJ, Holling CS. 1990. Large scale management experiments and learning by doing. Ecology 71(6): 2060-2068.

Ward JV, Stanford JA. 1995. The serial discontinuity concept: extending the model to floodplain rivers. Regulated Rivers: Research and Management 10(2-4): 159-168.

Ward JV, Tockner K. 2001. Biodiversity: towards a unifying theme for river ecology. Freshwater Biology 46(6): 807-819.

Ward JV, Tockner K, Schiemer F. 1999. Biodiversity of floodplain river ecosystems: ecotones and connectivity. Regulated Rivers: Research and Management 15: 125-139.

Wheaton JM, Pasternack GB, Merz JE. 2004. Spawning habitat rehabilitation-II. Using hypothesis development and testing in design, Mokelumne River, California, USA. International Journal of River Basin Management 2(1): 21-37.

Wilhere GF. 2002. Adaptive management in habitat conservation plans. Conservation Biology 16(1): 20-29.

Wissmar RC, Swanson FJ. 1990. Landscape disturbance and lotic ecotones. In The Ecology and Management of Aquatic Terrestrial Ecotones. Man and the Biosphere Series 4, Naiman RJ, Decamps H (eds). UNESCO: Paris; 65-102. 